\title{
Hepatic neoplasms in winter flounder Pleuronectes americanus from Boston Harbor, Massachusetts, USA
}

\author{
Michael J. Moore, John J. Stegeman \\ Biology Department, Woods Hole Oceanographic Institution, Woods Hole, Massachusetts 02543, USA
}

\begin{abstract}
Deer Island Flats, Boston Harbor, Massachusetts, USA, is an area that is heavily contaminated with organic and inorganic chemicals. At this site winter flounder Pleuronectes americanus have been found to have a high prevalence of hepatic lesions including neoplasms. We describe here the relative frequency and histology of different tumor types in a sample of 60 neoplasms from 29 fish. Ninety percent of tumors were cholangiocellular and ranged from cholangiomas to tubular, scirrhous, solid or cystic anaplastic cholangiocarcinomas. Hepatocellular tumors were also occasionally present $(10 \%)$. The majority of tumors were closely associated with hydropically vacuolated cholangiocytes and hepatocytes, often being observed within grossly visible aggregations of vacuolated cells, and with vacuolated cells at their advancing margins. Vacuolated cells may be involved in the progression to neoplasia.
\end{abstract}

KEY WORDS: Environmental carcinogenesis - Tumor biology · Cholangiocarcinomas

\section{INTRODUCTION}

Epizootics of hepatic neoplasia have been described in a number of bottom-feeding fish species from freshwater, estuarine, and marine habitats. Where examined in detail there are statistically strong relationships between tumor prevalence and the concentrations of chemical contaminants in the sediments (Landahl et al. 1990, Myers et al. 1994), and it appears that in most cases there is a chemical etiology (Harshbarger \& Clark 1990). Factors contributing to the origin and progression of these diseases have not been fully established. A thorough knowledge of the diversity of pathologies may aid in establishing the nature and species differences in these factors.

Hepatic neoplasms and other cellular lesions, including hydropically vacuolated cells (Bodammer \& Muchelano 1990), have been described in winter flounder in Boston Harbor, Massachusetts, USA, for a decade (Murchelano \& Wolke 1985, 1991, Gardner \& Pruell 1988). As in other systems these lesions appeared to be caused by chemicals. Sediments in
Boston Harbor contain high levels of polynuclear aromatic hydrocarbons, halogenated hydrocarbons, and heavy metals (Boehm 1984, Shiaris \& Jambard-Sweet 1986, NOAA 1988), many of which are suspected carcinogens. Furthermore, a survey of chemical contaminants and winter flounder liver pathology at 22 stations showed chemical contaminants to correlate most strongly with prevalence of hydropic vacuolation (Johnson et al. 1992). Although the condition and its chemical association have been described, there has been neither a systematic description of the diversity and relative frequency of the neoplasms present, nor an analysis of the degree of association between each neoplasm type, and hydropic vacuolation.

Here we describe and classify the spectrum of tumor phenotypes present in winter flounder from Boston Harbor from 1985 to 1990 , quantify the relative prevalence of each tumor type, and examine the spatial relationship between each tumor type and the various stages of hydropic vacuolation. Knowledge of this diversity and cellular association will be useful in analyzing differences in the cellular origins of specific 
lesions and for comparing lesions and their pathogenesis in different species of fish. Furthermore, information on cell types intimately associated with the progression to neoplasia within the relatively primitive organization of the teleost liver may be significant in aiding the understanding of hepatocarcinogenesis in the more complex mammalian liver system.

\section{METHODS}

Fish. Winter flounder were caught either by otter trawl or hook and line in a variety of sampling efforts in the years 1985 to 1990 . Fish were either necropsied at once, or returned to the laboratory alive. In the laboratory, fish were maintained in running filtered sea water at ambient temperature and then examined, usually within $48 \mathrm{~h}$, although some fish were held for longer periods.

Fish were killed by cervical section, and then opened by a ventral incision around the margin of the abdominal cavity. For fish caught in 1989 and 1990 a sample of scales was removed from the dorsal caudal peduncle, and submitted for age analysis by the National Marine Fisheries Service, Woods Hole, MA. The liver was dissected free of peritoneal attachments and examined for surface abnormalities, and then cut into $4 \mathrm{~mm}$ slices. Each slice was examined for grossly visible lesions. Altemate slices were preserved in neutral buffered formalin or liquid nitrogen. All fixed tissue was processed if gross lesions were visible. If no lesions were evident at necropsy, 1 slice was processed for histology. Frozen samples were archived for other studies. Protocols for the maintenance, examination and euthanasia of fish used in this study were approved by the Institutional Animal Care and Use Committee of the Woods Hole Oceanographic Institution.

Processing. Samples for histology were routinely dehydrated, embedded in paraffin and stained with hematoxylin and eosin. Adjacent sections from selected fish were stained (Luna 1968) for glycogen by the periodic acid Schiff method, collagen by Masson trichrome stain, Menzie's stain for nucleic acids and Gomori's stain for iron.

Histologic evaluation. ${ }^{1}$ Histopathologic categories included non-neoplastic and neoplastic lesions. (1) Cholangial hyperplasia: increased number of duct and ductular profiles, but with normal biliary architecture, with or without surrounding fibroplasia. (2) Hydropic vacuolation: a cell or cells with a large non-

\footnotetext{
${ }^{1}$ Cases that have been deposited at the Registry of Tumors for Lower Animals, at the Smithsonian Institution in Washington, DC, are identified with a Tumor Registry Accession Number (RTLA no.)
}

staining cytoplasmic vacuole, and a small basophilic nucleus. Seen singly in the center of the hepatic tubule, in tubular arrays, and in grossly visible foci. (3) Macrophage aggregation: aggregations of large, golden-brown macrophages often present adjacent to larger blood vessels and biliary structures. (4) Necrosis: cell death characterized by nuclear pyknosis and fragmentation, with cytoplasmic eosinophilia and swelling. (5) Hepatocellular neoplasms: focal masses of altered hepatocytes having obvious basophilic cytoplasm and large round nuclei with prominent nucleoli. These cells formed trabecular arrays. (6) Cholangiocellular neoplasms: less cytoplasm, a lesser degree of basophilia, and smaller oval nuclei with less distinct nucleoli than hepatocytes with a tendency, to varying degrees, to form tubules. Cholangiocellular lesions were classed as bearing 1 or more of the following characteristics: tubular, solid, cystic, papillary and scirrhous. Neoplastic lesions were staged as benign if the surrounding parenchyma was compressed but not invaded, the neoplastic cells were well differentiated, and if few mitotic figures were present. In contrast, carcinomas were invasive structures with cells lacking an obvious terminal phenotype. Cells in these poorly differentiated structures had nuclei of diverse size and shape and, at times, a high mitotic index. Extra-hepatic organs were examined visually but not histologically in this study, so the presence or absence of micro-metastases could not be determined.

Statistics. The significance of observed differences between lesion prevalence in males and females was tested by $\chi^{2}$ test. Differences between mean length of fish of each gender that did and did not contain neoplasms were tested for significance by the Student's $t$-test.

\section{RESULTS}

Fish

A total of 293 winter flounder (198 females, 87 males and 8 gender unrecorded) from Deer Island Flats (Boston Harbor) were examined grossly and histologically, in the period 1985 to 1990 . One or more hepatic neoplasms were found in $29 / 293(9.9 \%)$ of the fish examined (data were available on the gender of all fish with neoplasia). For the fish for which age data was available, the age of tumor-bearers ranged from 5 to 8 yr. The difference between the prevalence of neoplasia in males compared to females was insignificant (males $11.5 \%$, females $9.6 \%, \chi^{2} p=0.84$ ). Analysis of mean total length showed that female fish with neoplasms were significantly longer than those without neoplasms $(396 \pm 32 \mathrm{~mm}, \mathrm{n}=19$ vs $370 \pm 39 \mathrm{~mm}, \mathrm{n}=$ 
$179 ;$-test $\mathrm{p}=0.0055)$. The same trend was present for males, but it was not statistically significant $(357 \pm$ $16 \mathrm{~mm}, \mathrm{n}=10$ vs $338 \pm 48 \mathrm{~mm}, \mathrm{n}=77$; -test $\mathrm{p}=0.21$ ).

\section{Gross hepatic lesions}

Gross lesions were seen as translucent gray and pearly white foci and other less regular fleshy and cystic swellings on the surface and in the body of the liver. One or more of these were present in 59/293 (20.1\%) of all fish examined. Histological evidence of neoplasia was found in $28 / 59$ (47.5\%) of the grossly abnormal fish. An additional histological neoplasm was observed in a grossly normal individual. Thus, gross lesions were present in $28 / 29(96.5 \%)$ of fish containing histological evidence of neoplasia.

The diversity of gross lesions observed is illustrated in Fig. 1. The most common appeared as single or multiple raised creamy white nodules, both on the surface and deep in the tissue (Fig. 1a). These nodules varied in size from 2 to $20 \mathrm{~mm}$ in diameter. Additional gray, translucent lesions 2 to $8 \mathrm{~mm}$ in diameter were seen flush with the surface and were less nodular. Histologically, the white and the gray lesions consisted of large focal aggregations of vacuolated cells (Bodammer \& Muchelano 1990, Moore 1991). Some of these aggregations contained neoplastic lesions within the focus.

Less common lesions included 5 to $30 \mathrm{~mm}$ fleshy masses, often the same color as the surrounding tissue, as shown in Fig. 1b. A final gross lesion type consisted of multi-loculated cysts that were thin-walled as opposed to fleshy and filled with sero-sanguineous fluid (Fig. 1c). These lesions were exudative papillary cholangiocellular neoplasms histologically (see Fig. 7).

\section{Non-neoplastic cells associated with neoplastic lesions}

Previously described (Murchelano \& Wolke 1985, Moore et al. 1989, Bodammer \& Murchelano 1990) non-neoplastic yet abnormal lesions in winter flounder from Boston Harbor included, in order of decreasing prevalence: (1) macrophage aggregations, (2) hydropically vacuolated cells, (3) biliary duct hyperplasia, (4) undifferentiated spindle-shaped cells within a focus of vacuolated cells, and (5) tinctorially altered foci of hepatocytes (these were seen rarely). In the present study we found that, of the above lesions, only the vacuolated cells were found in intimate association with neoplastic lesions.

Vacuolated cells were associated with hepatocellular and cholangiocellular neoplastic lesions in 1 or both of 2 primary ways. First, as large grossly visible foci of vacuolated cells, often containing smaller areas of neoplastic cells. Secondly, single or multiple vacuolated neoplastic cells sometimes occurred within the body and/or around the invading edge of a neoplastic focus. The interrelationships between vacuolated cells and neoplastic lesions are summarized in Table 1

\section{Histochemistry}

Twelve fish, including 6 neoplasm-bearers, were stained histochemically for iron, collagen, glycogen and nucleic acids.

Iron. Non-neoplastic hepatocytes showed variable, but at times intense deposits of cytoplasmic iron. Macrophage aggregations also stained intensely for iron. In contrast, all hepatocellular and cholangiocellular neoplastic lesions present in $6 / 6$ different fish did not stain. Intra-vacuolar material in vacuolated cells also did not stain for iron.

Collagen. Collagen commonly surrounded proliferated bile ducts, and interwove many of the larger neoplastic lesions. Staining showed that fibrous connective tissue filled the voids that seemed to be associated with degeneration of neoplastic tissue. Intravacuolar material in hydropically vacuolated cells did not stain

Glycogen. Glycogen was present in the cytoplasm of some hepatocytes of Boston Harbor fish. Brush borders of some neoplastic cholangiocytes also stained positively for collagen. Vacuolated cells did not stain.

Table 1 Pleuronectes americanus. Winter flounder caught on Deer Island Flats, Boston Harbor, MA, between 1985 and 1990 Proportions of neoplastic lesions intermingled by, in foci of, and fringed by vacuolated cells (vc); 23 fish contained 1 or more cholangiocellular neoplasms, 5 contained 1 or more hepatocellular neoplasms, and 1 contained both hepatocellular and cholangiocellular lesions. Neoplasms and their relationship to vacuolated cells are described in the text. Neoplasms were classed as distinct if there was obvious spatial and phenotypic discontinuity between adjacent lesions

\begin{tabular}{|lcccc|}
\hline Neoplasm type & $\begin{array}{c}\text { Number of } \\
\text { neoplasms }\end{array}$ & $\begin{array}{c}\text { \% of neoplasms } \\
\text { containing vc }\end{array}$ & $\begin{array}{c}\text { \% of neoplasms } \\
\text { in foci of vc }\end{array}$ & $\begin{array}{c}\% \text { of neoplasms } \\
\text { fringed with vc }\end{array}$ \\
\hline Hepatocellular & 6 & 17 & 17 & 100 \\
Cholangiocellular & 54 & 37 & 65 & 91 \\
\hline
\end{tabular}




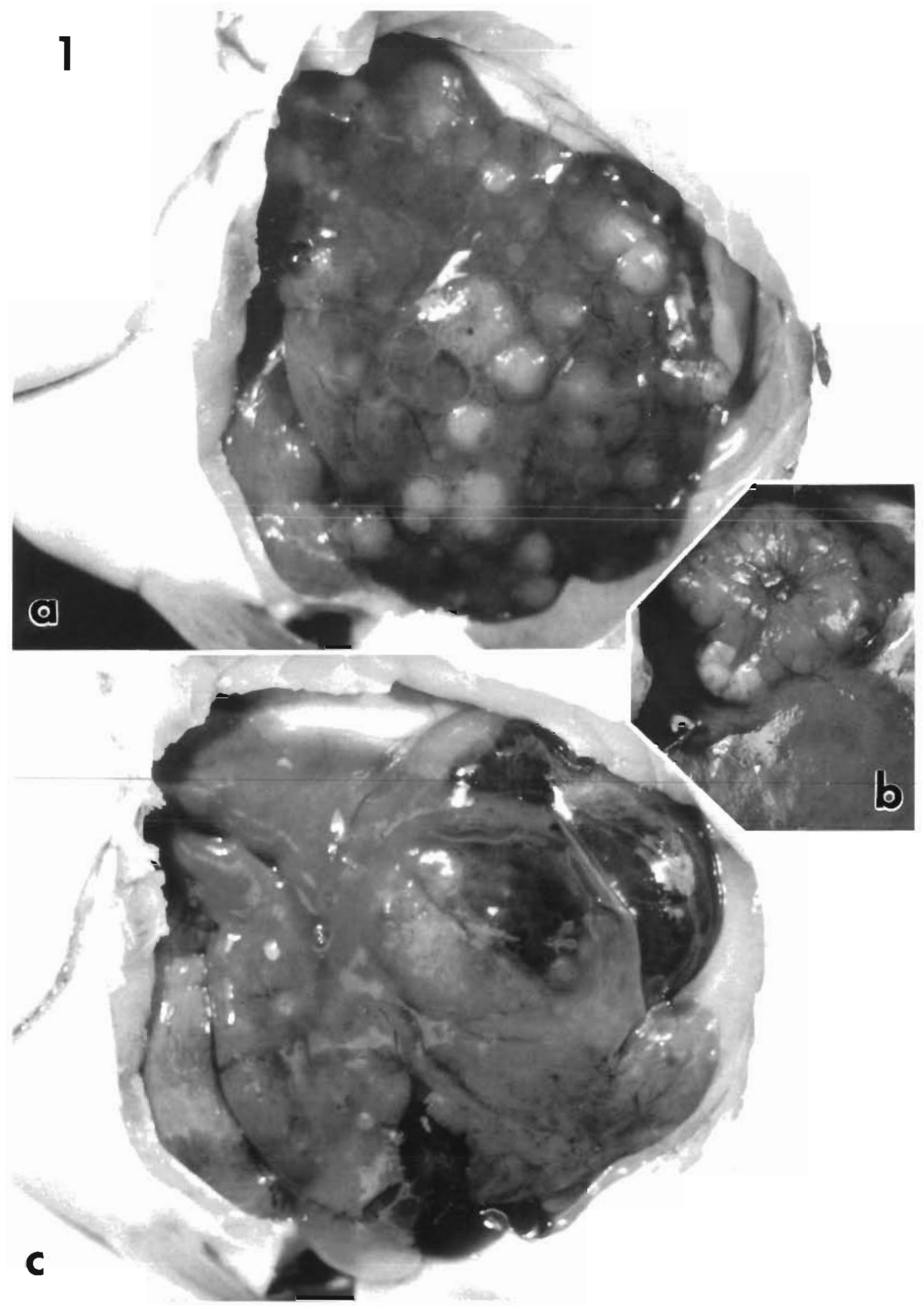

Fig. 1. Pleuronectes americanus. Ventral views of exposed surfaces of winter flounder livers from fish caught on Deer Island Flats, Boston Harbor. The liver lies below the ventral body wall that has been cut away. The opercular flap is visible to the left. (a) RTLA no. 5233. Multiple creamy white nodules pervade the liver. Additional non-nodular clear patches are also evident. Histologically this liver had approximately 50 distinct neoplastic lesions and foci of vacuolation. Neoplastic cell types involved a spectrum of cholangiocellular phenotypes. 1.5×. (b) RTLA no. 5229. A large fleshy umbilicated hepatic mass is seen overlyng the stomach. A small creamy lesion is adjacent. Histologically both of these lesions were cholangiomas. 1.1x. (c) RTLA no. 5231. The major portion of the liver in this fish consisted of distended cysts, filled with serosanguineous fluid. Histologically these lesions were cystic and papillary cholangiocarcinomas. $1.1 \times$ 
Table 2. Pleuronectes americanus. Histo-morphological characteristics of neoplastic lesions in winter flounder from Deer 1 sland Flats. Sizes are as compared to untransformed hepatocytes or cholangiocytes

\begin{tabular}{|c|c|c|c|c|c|c|c|}
\hline Lesion type & $\begin{array}{c}\text { Tissue } \\
\text { architecture }\end{array}$ & $\begin{array}{l}\text { Invasion of } \\
\text { parenchyma }\end{array}$ & Nucleus & Nucleolus & $\begin{array}{l}\text { Cytoplasm } \\
\text { staınung }\end{array}$ & $\begin{array}{l}\text { Nucleus:cyto- } \\
\text { plasm ratio }\end{array}$ & Cell size \\
\hline $\begin{array}{l}\text { Hepatocellular } \\
\text { adenoma }\end{array}$ & Trabecular & - & $\begin{array}{l}\text { Round, } \\
\text { monomorphic }\end{array}$ & Varıable & Basophilic & Normal & Large \\
\hline $\begin{array}{l}\text { Hepatocellular } \\
\text { carcinoma }\end{array}$ & Trabecular & + & $\begin{array}{l}\text { Round, } \\
\text { pleomorphic }\end{array}$ & Prominent & Basophilic & High & Large \\
\hline Cholangioma & Tubular & - & $\begin{array}{l}\text { Circular to } \\
\text { ellipsoid }\end{array}$ & Variable & $\begin{array}{l}\text { Normal to } \\
\text { eosinophilic }\end{array}$ & Low/normal & Large \\
\hline \multirow{4}{*}{$\begin{array}{l}\text { Cholangio- } \\
\text { carcinoma }\end{array}$} & Tubular & + & Ovoid & Small & Eosinophilic & Normal & Normal \\
\hline & Solid & + & Ellipsoid & None & Eosinophilic & High & Small \\
\hline & $\begin{array}{l}\text { Scirrhous: inter- } \\
\text { woven with } \\
\text { fibrotic sheets }\end{array}$ & + & $\begin{array}{l}\text { Ovoid or } \\
\text { ellipsoid }\end{array}$ & & & & \\
\hline & $\begin{array}{l}\text { Cystic: lined } \\
\text { with flattened } \\
\text { cholangiocytes }\end{array}$ & + & Ellipsoid & None & Eosinophilic & High & Small \\
\hline
\end{tabular}

Nucleic acids. Menzie's stain showed DNA to be in the nuclei, and RNA to be in the nucleolus and nonvacuolated cytoplasm of all cells. The vacuolar material within the hydropically vacuolated cells did not stain for either DNA or RNA.

\section{Diversity of neoplastic phenotypes}

Every neoplastic lesion was unique, yet many fell within definable categories. Cholangiocellular neoplasms proved to be most common $187 \%$ of all histologically distinct neoplastic lesions) although they were extremely heterogeneous. The cholangiocellular types included cholangiomas and tubular, solid, cystic, and papillary cholangiocarcinomas. The hepatocellular types included adenomas and carcinomas. The histo-morphological characteristics of each neoplasm type are given in Table 2, the prevalence of each lesion type is listed in Table 3 , and Table 4 lists selected individual cases.

\section{Hepatocellular adenomas}

These were rare; only 3 such cases were observed. Fig. 2a shows 1 of these lesions that was walled off with a fibrous capsule that compressed the adjacent parenchyma. This lesion appeared to have overgrown and displaced a focus of vacuolated cells with sheets of hepatocytes whose nuclei were round with prominent nucleoli, and whose cellular outlines were indistinct, but generally rhomboid. Vascular sinusoids permeated the lesion. However, hepatocyte tubules had multiple cell layers between each canaliculus and sinusoid, in contrast to the normal single layer arrangement. Vacuolated cells were irregularly interspersed through the body and edges of the focus.

\section{Hepatocellular carcinomas}

Pleomorphic hepatocellular lesions were seen only in 3 fish. These appeared as small 1 to $2 \mathrm{~mm}$ invasive lesions, more basophilic than the surrounding parenchyma (Fig. 2b). Nuclear profiles in these cells were round and had prominent nucleoli, but their size was variable, with some nuclei being twice the size of those in non-neoplastic hepatocytes in the adjacent

Table 3. Pleuronectes americanus. Type and relative frequency of 60 distinct neoplastic lesions in 29 flounder collected from Deer Island Flats. Lesions are described in the text, and in Table 2. Lesions were classed as distinct if there were obvious spatial and phenotypic discontinuities

\begin{tabular}{|lrr|}
\hline & $N$ & $\%$ \\
\hline Hepatocellular adenoma & 3 & 5.0 \\
Hepatocellular carcinoma & 3 & 5.0 \\
Cholangioma & 2 & 3.3 \\
Cholangiocarcinoma & & \\
Tubular & 15 & 25.0 \\
Solid & 18 & 30.0 \\
Tubular/solid & 7 & 11.7 \\
Tubular/scirrhous & 4 & 6.6 \\
Tubular/cystic & 7 & 11.7 \\
Cystic/scirrtous & 5 & 8.3 \\
Cystic/papillary & 2 & 3.3 \\
\hline
\end{tabular}


Table 4. Pleuronectes americanus. Hepatic neoplastic lesions in winter flounder from Deer Island Flats, described in this paper and archived at the Registry of Tumors for Lower Anımals, Washington, DC. Multuple lesions from the same, or different tissue block of 1 individual have the same RTLA no

\begin{tabular}{|c|c|c|c|c|}
\hline & $\begin{array}{l}\text { RTLA } \\
\text { no. }\end{array}$ & $\begin{array}{l}\text { Length } \\
(\mathrm{mm})\end{array}$ & Sex & $\begin{array}{l}\text { Lesion size } \\
\text { (mm) }\end{array}$ \\
\hline \multicolumn{5}{|l|}{ Hepatocellular } \\
\hline Trabecular & 5227 & 410 & $\mathrm{~F}$ & 20 \\
\hline \multirow{2}{*}{ Trabecular } & 5235 & 415 & $\mathrm{~F}$ & 1.8 \\
\hline & 5236 & 360 & $\mathrm{~F}$ & 1.2 \\
\hline \multicolumn{5}{|c|}{ Cholangiocellular (well differentiated) } \\
\hline & 5229 & 450 & $\mathrm{~F}$ & 30.0 \\
\hline & 5226 & 360 & M & 10.0 \\
\hline \multicolumn{5}{|c|}{ Cholangiocellular carcinoma (poorly differentiated) } \\
\hline \multirow[t]{4}{*}{ Tubular } & 5230 & 395 & $\mathrm{~F}$ & 1.0 \\
\hline & 5232 & 389 & $\mathrm{~F}$ & $8.0-16.0$ \\
\hline & 5233 & 395 & $\mathrm{~F}$ & $1.4-4.8$ \\
\hline & 5226 & 360 & $\mathrm{M}$ & 2.0 \\
\hline \multirow[t]{5}{*}{ Solid } & 5228 & 420 & $F$ & $2.0-3.6$ \\
\hline & 5230 & 395 & $F$ & 2.0 \\
\hline & 5233 & 375 & $F$ & 4.0 \\
\hline & 5234 & 398 & $F$ & 8.0 \\
\hline & 5237 & 360 & M & 2.1 \\
\hline Tubular/solid & 5228 & 420 & $\mathrm{~F}$ & 2.2 \\
\hline Tubular/scirrhous & 5233 & 375 & $F$ & 4.0 \\
\hline \multirow[t]{2}{*}{ Tubular/cystic } & 5225 & 390 & $M$ & 2.1 \\
\hline & 5228 & 420 & $F$ & 4.0 \\
\hline Cystic/scirrhous & 5225 & 390 & M & 2.0 \\
\hline \multirow[t]{2}{*}{ Cystic/papillary } & 5228 & 420 & $\mathrm{~F}$ & 3.3 \\
\hline & 5231 & 436 & $\mathrm{~F}$ & 27.0 \\
\hline
\end{tabular}

parenchyma. Mitotic figures were evident throughout the lesions. Lesions were at times heavily permeated by dilated vascular sinusoids. Invasion appeared as a radial intercalation of normal tubules by fingers of neoplastic hepatocytes.

\section{Cholangiomas}

As with hepatocellular lesions, non-invasive, differentiated, monomorphic cholangiocellular lesions were also rare. Only 2 cases were observed in this series. In 1 fish (RTLA no. 5229) a $30 \mathrm{~mm}$ diameter raised, um- bilicated lesion (Fig 1b) had a creamy white nodule on one surface. Histologically (Fig. 3) the entire lesion was a mass of densely packed biliary tubules. Many of the tubules lacked a lumen. In the center of the lesion, nests of dilated tubules were seen, lined with cuboidal epithelia and filled with eosinophilic cellular debris. Portions of the center of the lesions were necrotic, with extensive scirrhous cords of eosinophilic fibrous tissue running through the mass of neoplastic tissue. Nuclei varied from circular, to ovoid, to ellipsoid. Nucleoli varied from prominent to absent. The grossly visible but smaller adjacent, creamy protuberance consisted of a solid, non-tubular mass of neoplastic cholangiocytes. These cells were contiguous with the adjacent larger mass of tubules, and compressed but did not invade the overlying band of normal parenchyma.

\section{Tubular cholangiocarcinoma}

This subtype (Fig. 4), seen in 15 lesions, had many similarities to the cholangiocellular lesions described above, with obvious tubules. However, the cell margins were less distinct, the nuclear outlines were more variable, and the tumors were seen at times to invade rather than compress the adjacent parenchyma. Invasion appeared as a sinuous interweaving of neoplastic biliary tubules around normal tubules of hepatocytes. Vacuolated cells were common at the invasive edge of the tumor lesions.

\section{Solid cholangiocarcinoma}

Eighteen cholangiocellular neoplasms lacked an obvious tubular phenotype, with poorly differentiated cholangiocytes arranged in solid masses and whorls (Fig 5). Nuclei were smaller than those in the cells of the tubular subtype. The nuclei were elongated, pleomorphic, and irregular in outline and the nucleoli were indistinct. The eosinophilic cytoplasm had a low volume, except where hydropic vacuolation of neoplastic cells occurred. Many of these lesions were invasive, with masses of cells diffusely invading adjacent parenchyma.

Fig. 2. Pleuronectes amencanus. Hepatocellular neoplasms in winter flounder liver. Paraffin-embedded sections (H\&E). (a) RTLA no. 5227 Hepatocellular adenoma: a large fleshy hepatıc mass was evident grossly and histologically. Normal tubulosinusoidal structure was replaced by masses of monomorphic neoplastic hepatocytes $(N)$. No invasion was evident. The lesion was walled off by a thick fibrous capsule (F). Many of the cells in the surrounding parenchyma were vacuolated (V). 100x. (b) RTLA no. 5236. Hepatocellular adenocarcinoma: multiple 1 to $2 \mathrm{~mm}$ yellow lesions were observed grossly in this fish. An invasive trabecular focus is shown (arrowheads delineate border). $100 \times$ 


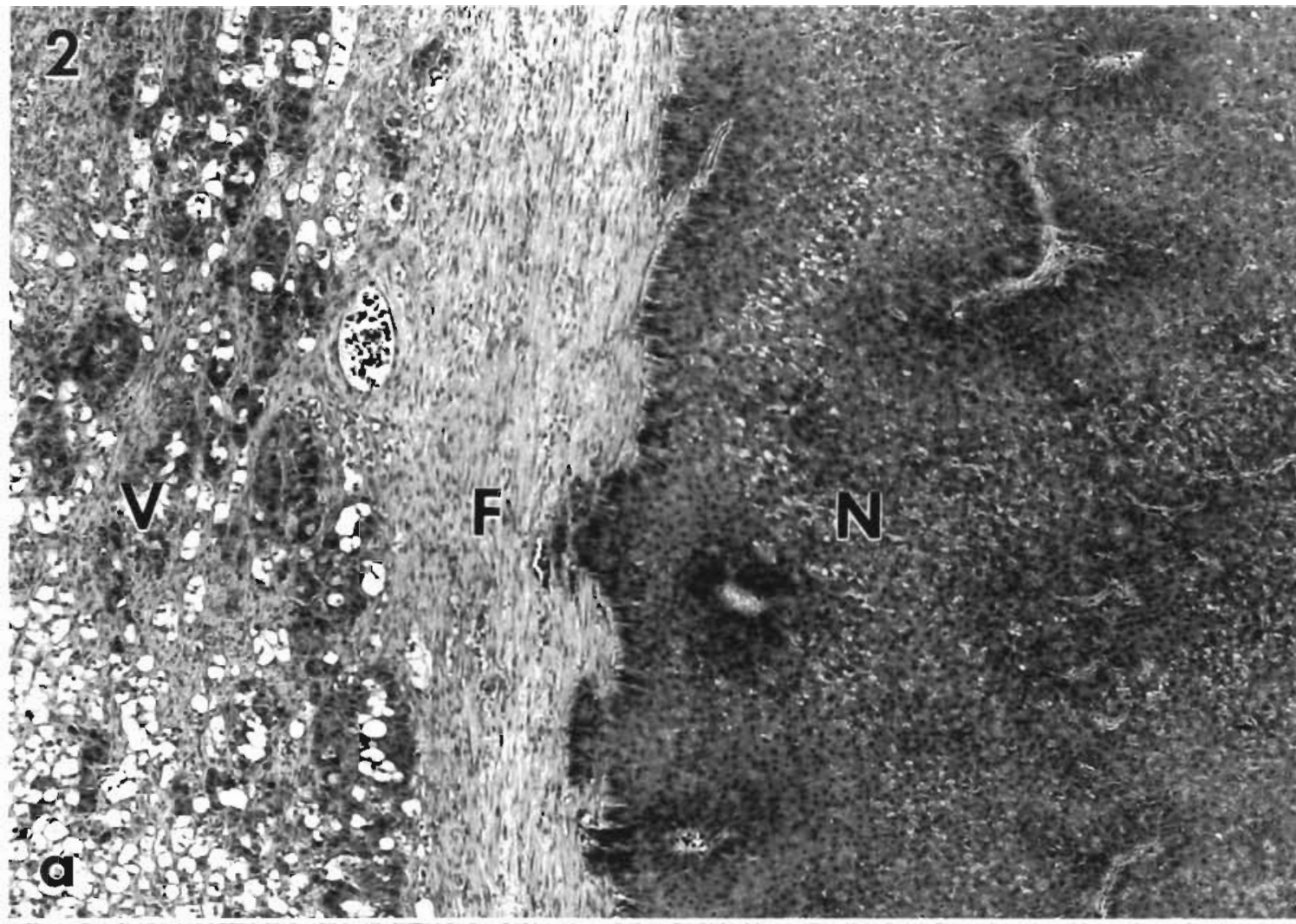

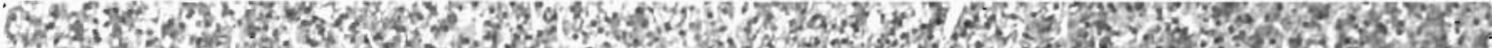

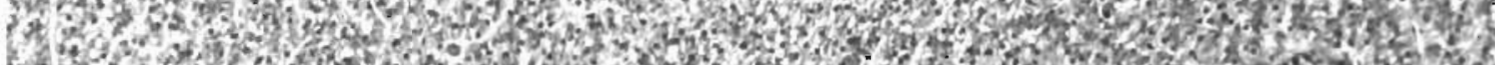

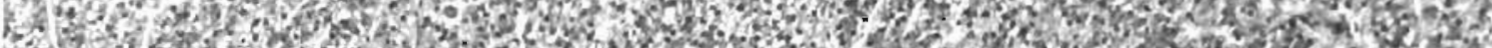

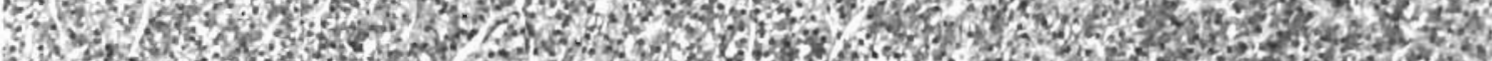

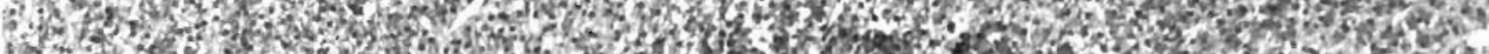

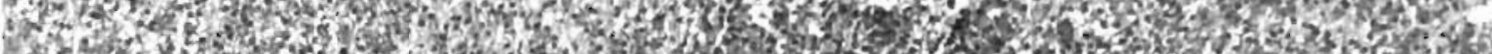

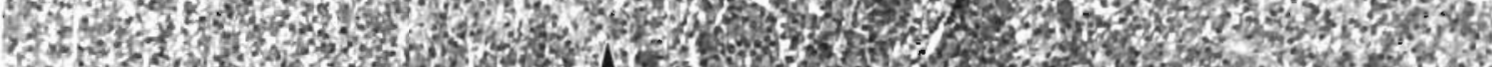

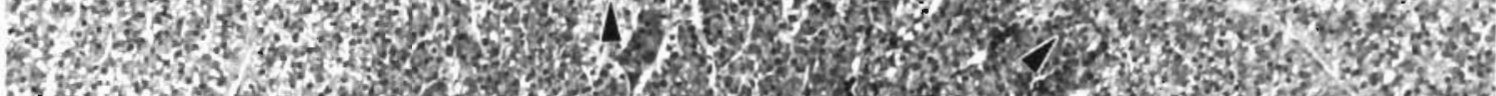

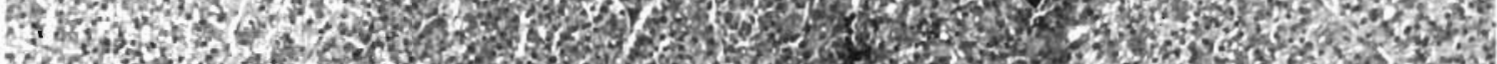

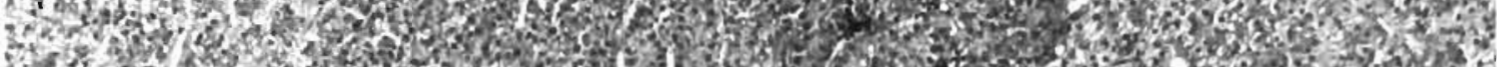

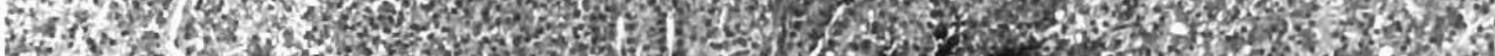

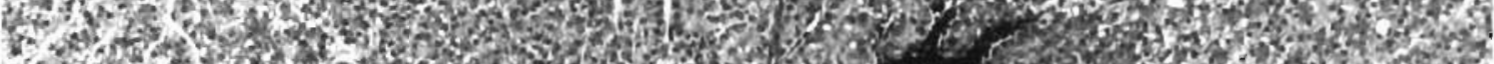

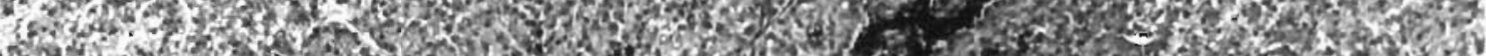

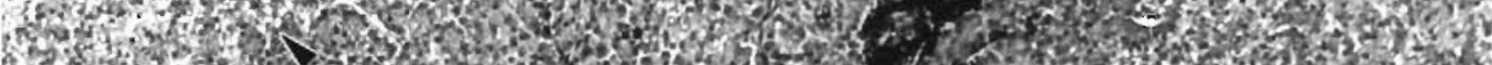

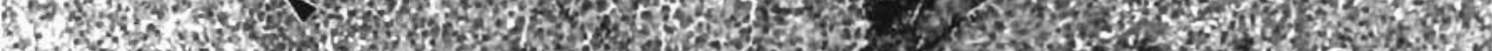

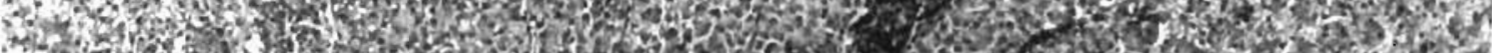

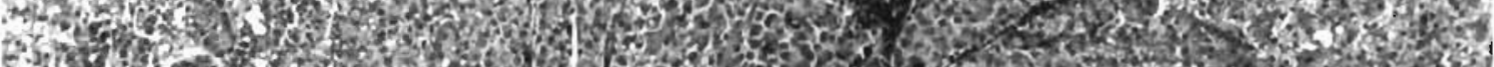

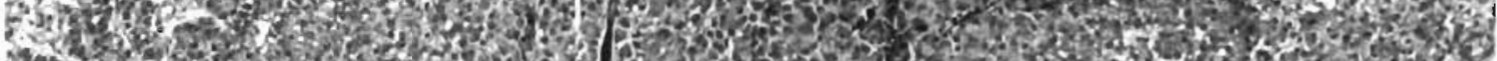

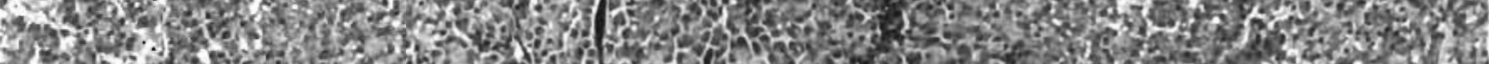

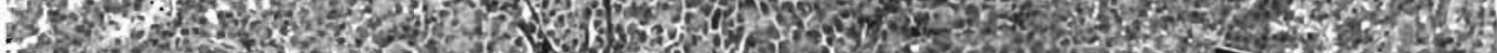

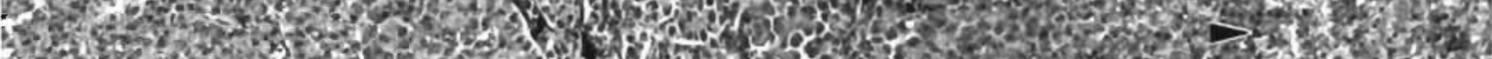

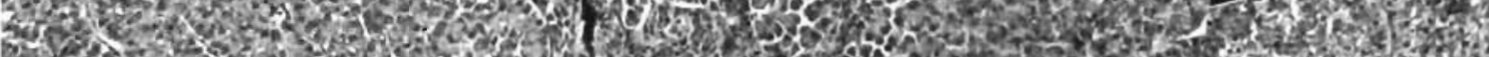

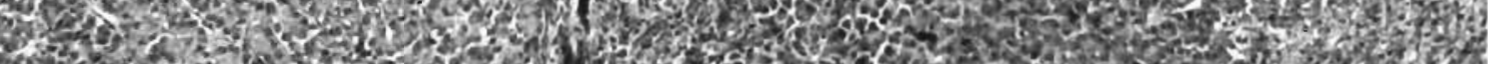

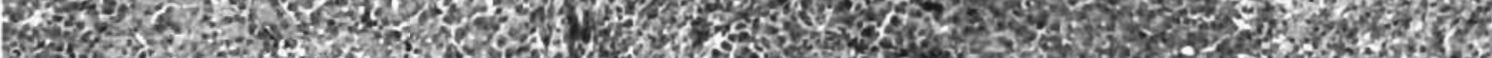

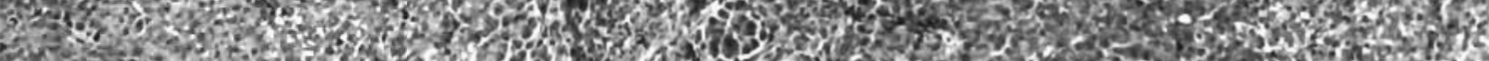
Ww

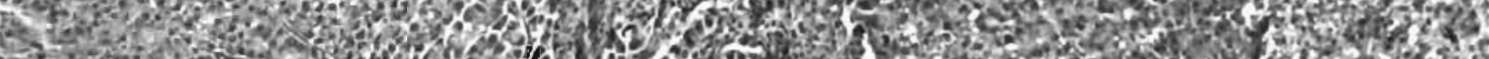

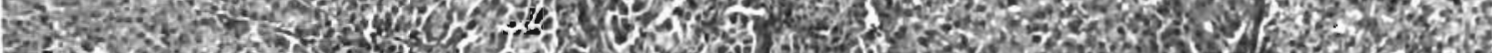

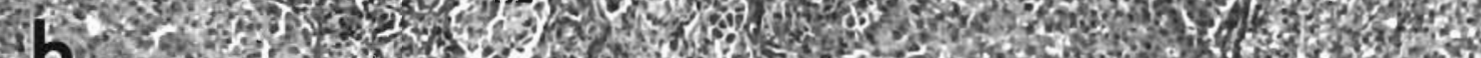

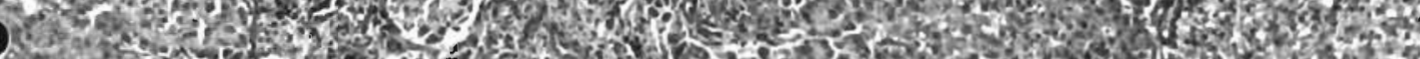
- 


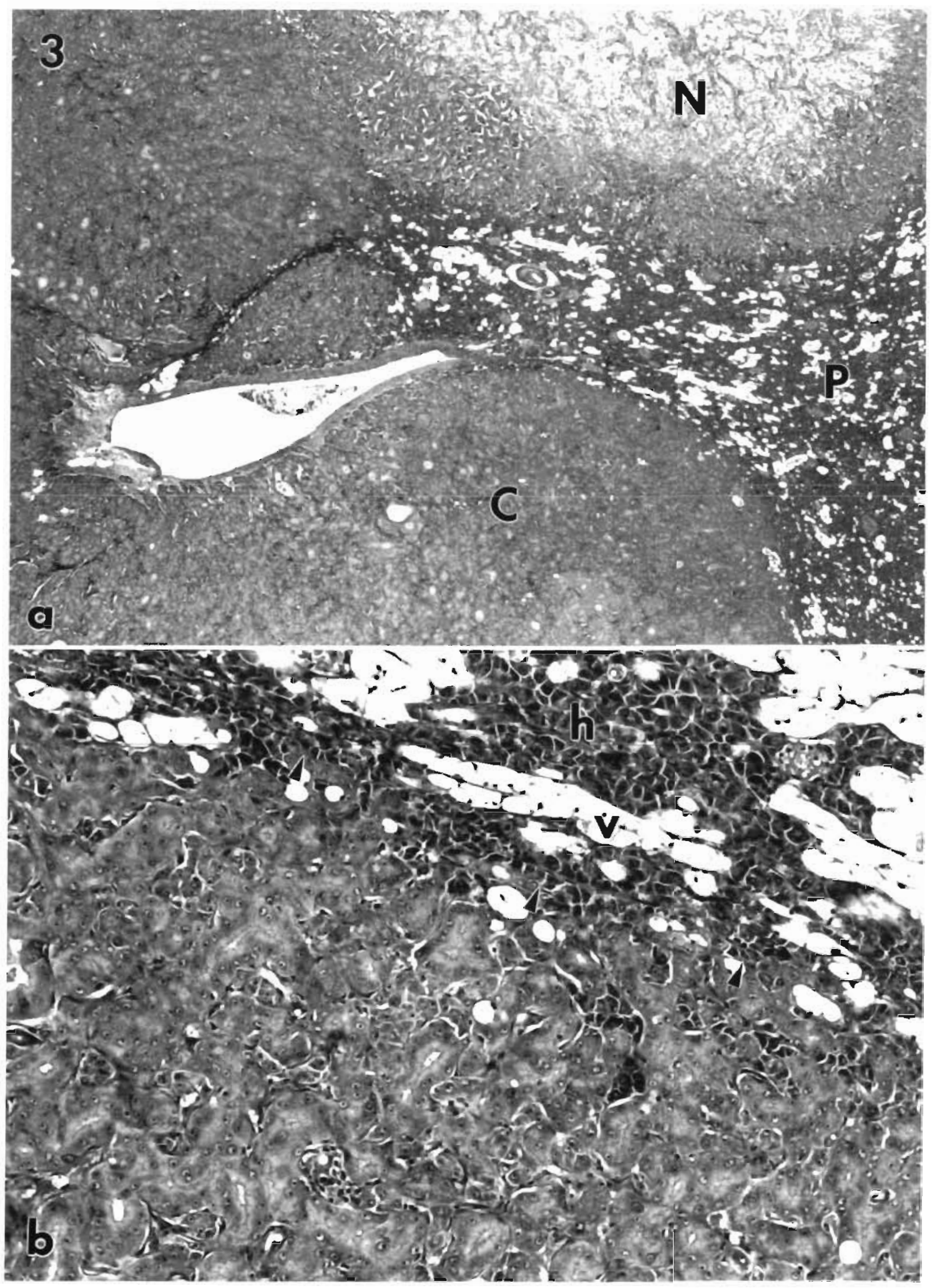

Fig. 3. Pleuronectes americanus. A large cholangioma in a winter flounder liver. Paraffin-embedded sections (H\&E). The gross appearance of this lesion is illustrated in Fig. 1b. RTLA no. 5229. (a) Cholangioma. Section through the border of the neoplasm. A solid mass of neoplastic tubules is present $(C)$, with a wedge of heavily vacuolated parenchyma $(P)$. Above this, a further lobe of the neoplasm is evident, with a necrotic center $(N) .25 \times$. (b) Detail of the area between ' $C$ ' and ' $P$ ' in (a). The tubular nature of the neoplasm is evident, with compression of adjacent parenchyma (arrowheads). The tubular stage of vacuolation is evident in the parenchyma, which consists of vacuolated cells (v) and basophllic hepatocytes (h). 200x 


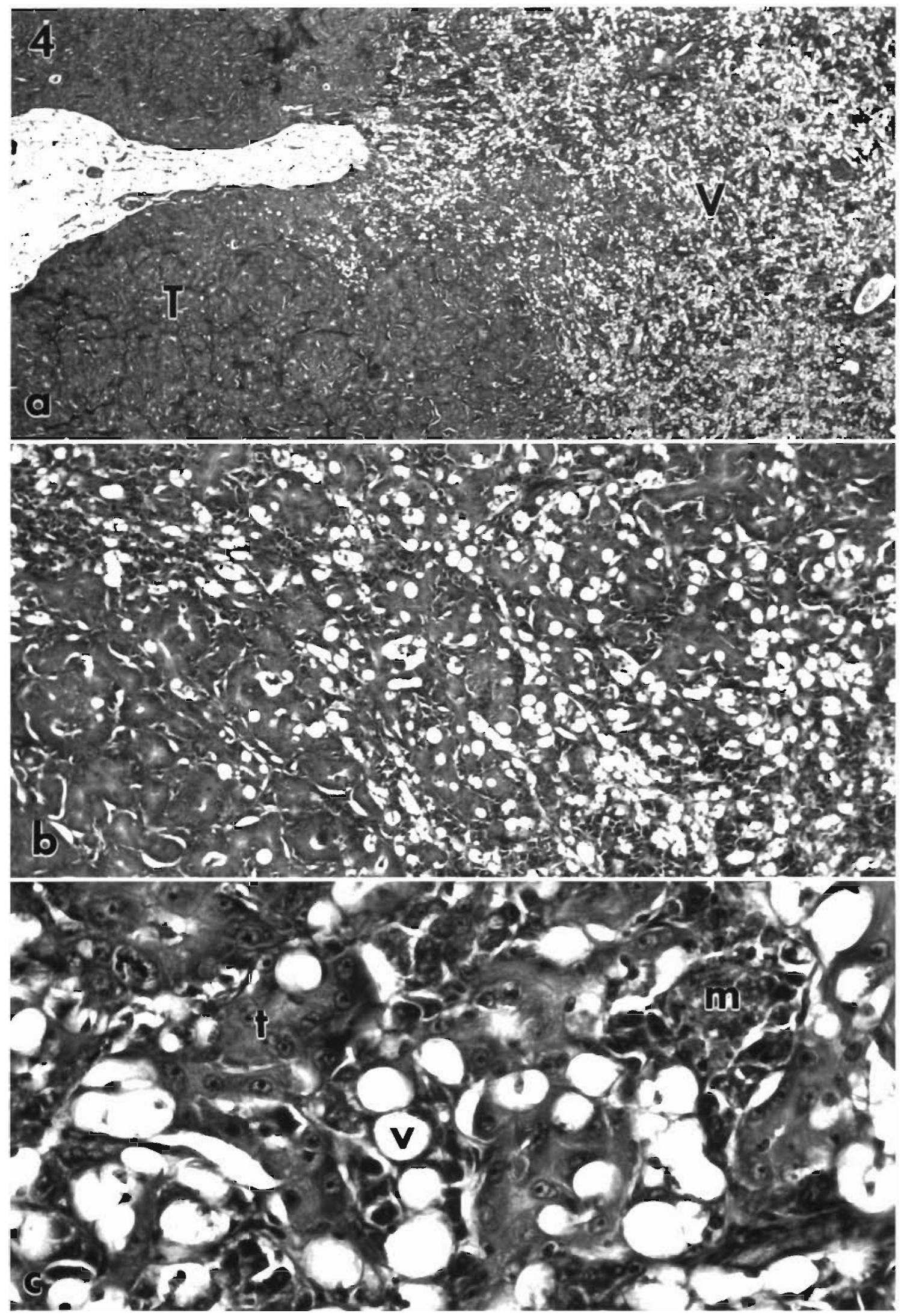

Fig. 4. Pleuronectes americanus. An invasive tubular cholangiocellular carcinoma in a winter flounder liver. Paraffin-embedded sections (H\&E). The gross appearance of this fish is illustrated in Fig. 1a. RTLA no. 5233. (a) A mass of biliary tubules (T). The neoplasm interdigitates an adjacent focus of vacuolated cells (V). 25×. (b) A higher magnification of the left edge of the neoplasm in (a). Note the close proximity of vacuolated and neoplastic cells. $100 \times$. (c) A higher magnification of (b). Vacuolated cells (v), neoplastic cholangiocytes (t), and a macrophage aggregate (m) are evident. $400 \times$ 


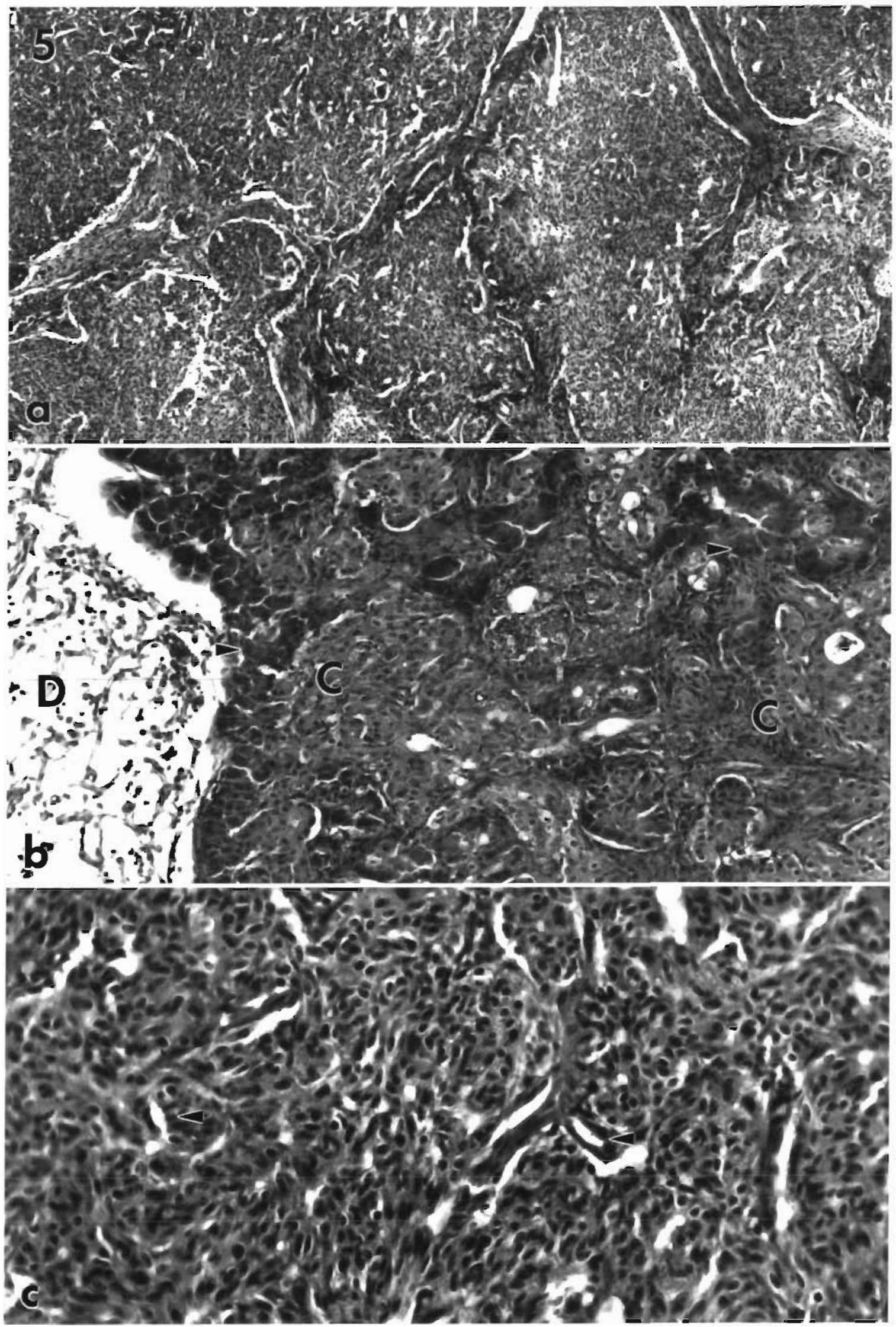




\section{Cystic cholangiocarcinoma}

Some tubular cholangiocellular neoplasms had areas dominated by more or less circular cysts and dilated tubules (Fig. 6), lined by small, flattened, cuboidal epithelia, with ellipsoid nuclei and sparse cytoplasm. In others, the entire lesion was cystic. Cysts were interspersed by more pleomorphic cholangiocytes typical of those described above in the solid tumor subtype.

\section{Papillary cholangiocarcinoma}

A minority of the cystic cholangiocellular lesions had papillary tufts growing into the cyst lumen. These tufts consisted of small poorly differentiated cells with scant cytoplasm (Fig. 7). Free macrophages were also present in the lumina of these cysts that contained papillary tufts. Some of these cysts had enlarged enormously to form grossly visible structures filled with sero-sanguineous fluid (see Fig. 1c)

\section{Degenerative changes in cholangiocellular neoplasms}

Fibrotic strands infiltrated many of the lesions. However, a few lesions showed an extensive fibrosis, giving a scirrhous appearance (Fig. 8a). These lesions appeared senescent, with whorls and tubules of neoplastic cholangiocytes intercalated by a swirling network of fibroblasts. These tracts were often continuous with spaces in the tumor focus, which were wholly or partially filled with desmoplastic fibrosis (Fig, 8c). In some lesions these spaces were filled with many smaller, empty structures lined by effete neoplastic cells, interspersed with single macrophages. This arrangement had the appearance of spongiosis hepatis (Bannasch et al. 1981, Couch 1991), and seemed to be the end stage of degeneration of the neoplastic focus (Fig. 8b).

\section{DISCUSSION}

In this study we have found that cholangiocellular neoplasms were the most common tumor in winter flounder sampled from Deer Island Flats in 1985 through 1990. In their 1984 sample Murchelano \& Wolke (1991) also found that hepatic tumors in winter flounder from Boston Harbor were predominantly cholangiocellular; our results thus establish that this general neoplastic phenotype is persistent over at least 7 yr. Cholangiocellular tumors have also predominated in some other bottom-feeding fish from contaminated sites, notably in the brown bullhead Ictalurus nebulosus (Baumann et al. 1987, Hayes et al. 1990) and the white sucker Catostomus commersoni (Hayes et al. 1990). In contrast, hepatacellular neoplasms were more common than cholangiocellular neoplasms in winter flounder from 10 U.S. East Coast sites (Johnson et al. 1992), English sole Pleuronectes vetulus (Myers et al. 1990) and the mummichog Fundulus heteroclitus (Vogelbein et al. 1990).

The predominance of hepatocellular neoplasms in fish from some contaminated sites, and cholangiocellular neoplasms from others, may involve some or all of the following factors: (1) differences in the nature of the chemical(s), in the dose(s) and/or in the duration of exposure at each site; (2) the unique spawning behavior, feeding habits and seasonal migration of each species; (3) differing genetic abilities to metabolize, activate and excrete carcinogens, and susceptibilities of protooncogenes and tumor suppressor genes to genotoxic deregulation. In addition, variability in diagnostic interpretation between studies should be considered.

Polynuclear aromatic hydrocarbons (PAH) are genotoxins that are most commonly found at high concentrations in contaminated sediments. Therefore, experiments in which PAH were administered to fish are relevant for understanding feral epizootics in contaminated habitats. Captive-bred species in which PAH have been used to induce liver tumors include the rainbow trout Oncorhynchus mykiss (Black et al. 1985. Hendricks et al. 1985), topminnow Poeciliopsis monacha (Schultz et al. 1989), guppy Poecilia reticulata (Hawkins et al. 1990) and medaka Oryzias latipes (Hawkins et al. 1990). Lesions resulting from experimental PAH exposure of fish as embryos, larvae or juveniles are usually described as hepatocellular, and are usually found in fish of 6 to 12 mo of age (Hoover 1984). Exposure of adult fish often fails to elicit overt

Fig. 5. Pleuronectes americanus. An invasive solid cholangiocellular carcinoma in a winter flounder liver. Paraffin-embedded sections (H\&E). The gross appearance of this fish is illustrated in Fig. 1a. RTLA no. 5233. (a) Masses and whorls of neoplastic cholangiocytic epithelia. $25 \times$. (b) A higher magnification of a different area of the same lesion as in (a). Masses of neoplastic cholangiocytes $(C)$ are interspersed with trabeculae of more basophilic non-neoplastic hepatocytes (arrowheads). A degenerative area (D) on the left margin has been filled in with spongiotic tissue. 100x. (c) Detail of part of (a). Occasional primitive tubular structures are evident (arrowheads). $400 \times$ 

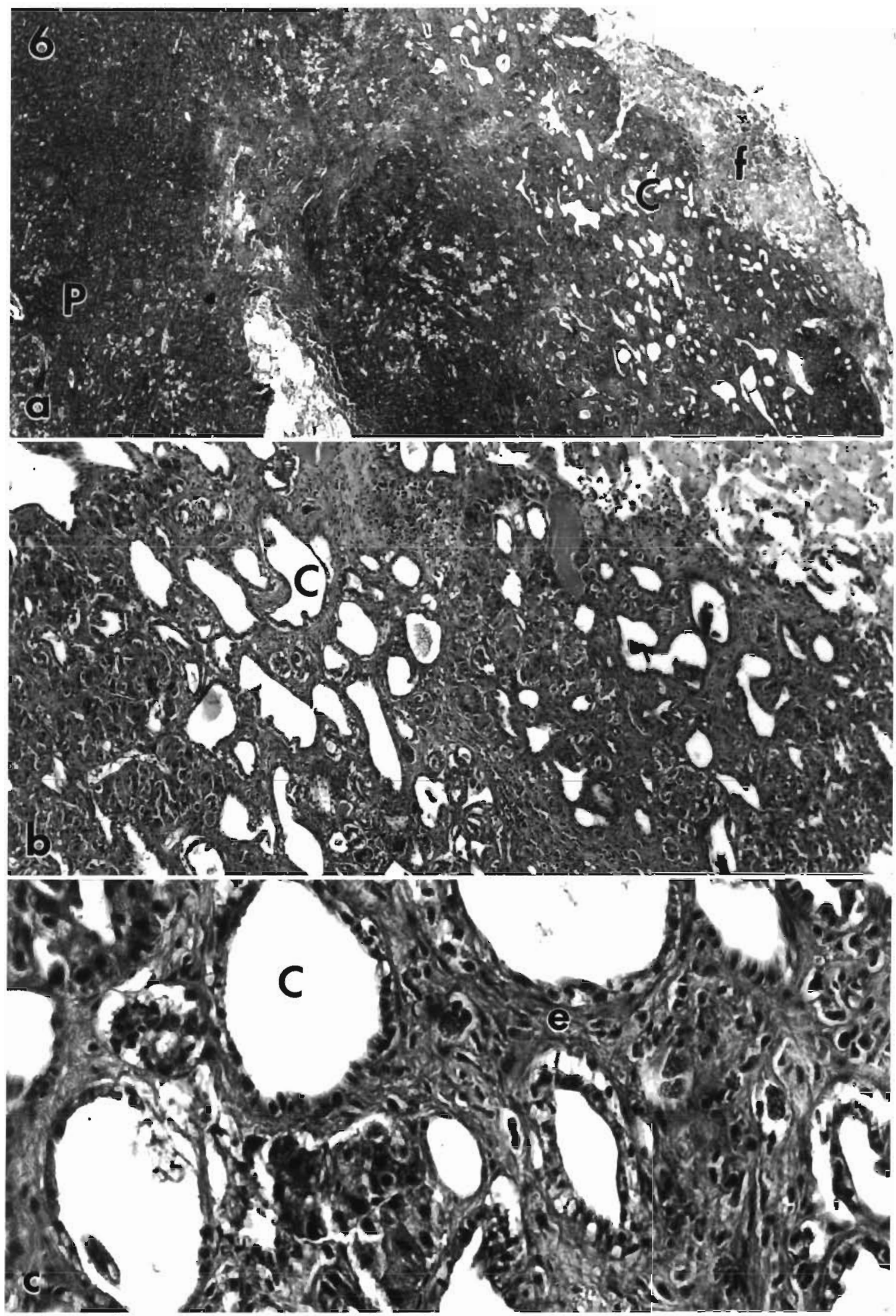

Fig. 6. Pleuronectes americanus. An invasive cystic cholangiocellular carcinoma in a winter flounder liver. Paraffin-embedded sections (H\&E). RTLA no. 5228. (a) Cystic cholangiocellular neoplastic tissue (C) is bordered by a fibrotic necrotic capsule (f); the parenchyma contains many vacuolated cells (P). $25 \times$. (b) $100 \times$ and (c) $400 \times$ of the lesion in (a). Multiple cysts (C) lined with small flattened cholangiocytes are surrounded by a stroma of similar cells (e) 


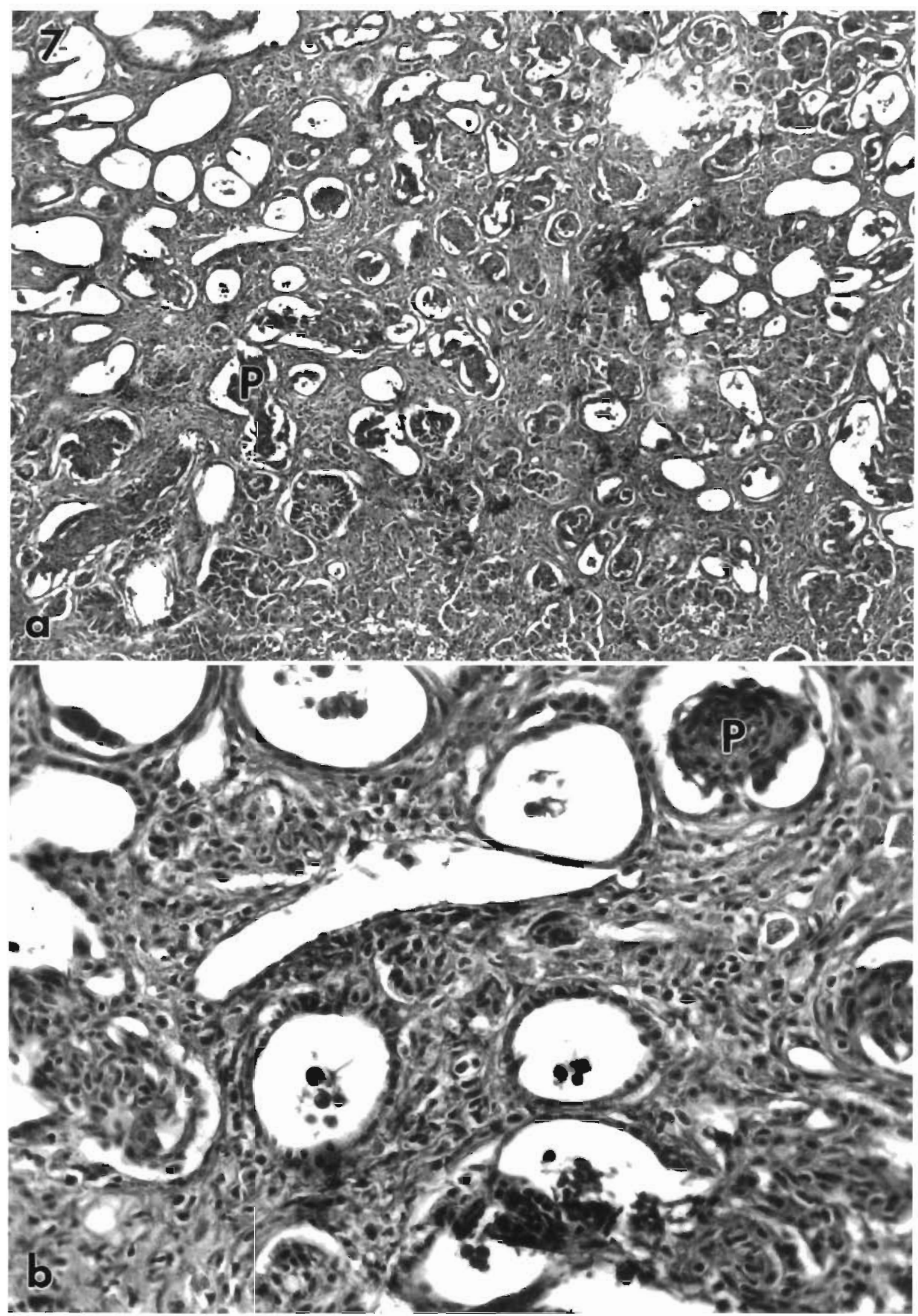

Fig. 7. Pleuronectes americanus. An invasive papillary cholangiocellular carcinoma in a winter flounder liver. Paraffin-embedded sections (H\&E). RTLA 5228. (a) 100x and (b) 400x: papillary tufts (P) are evident in the lumina of many of the cysts 


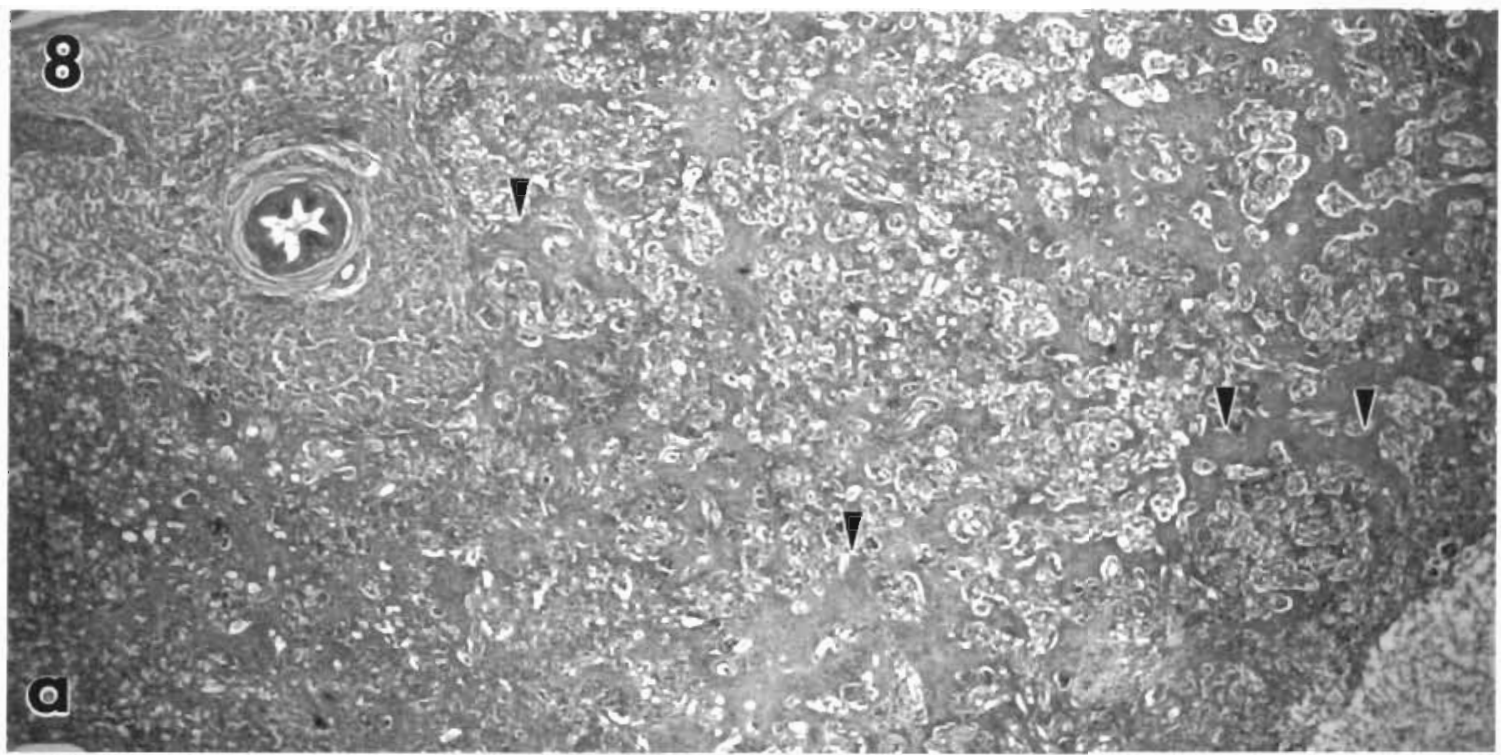

20.

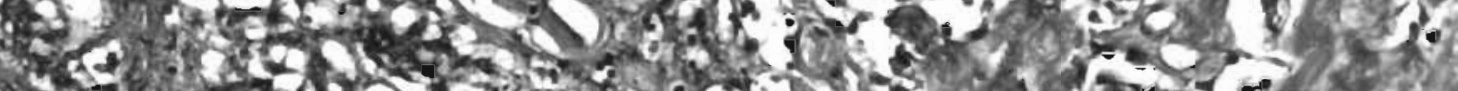

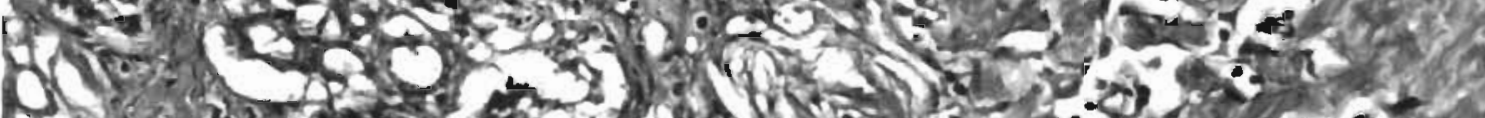

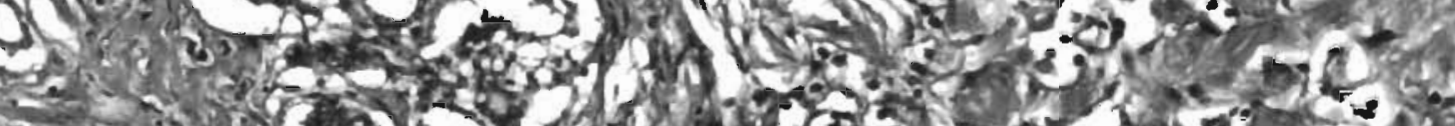
s. S.

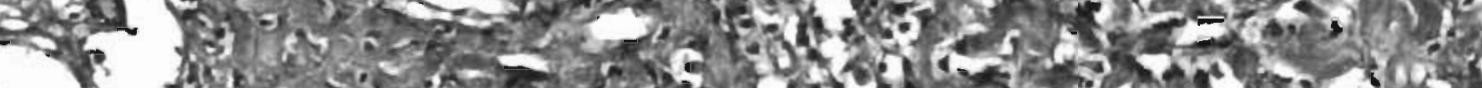

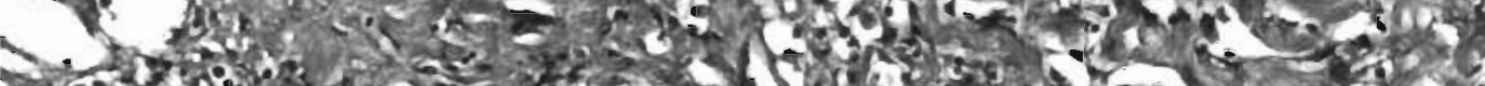

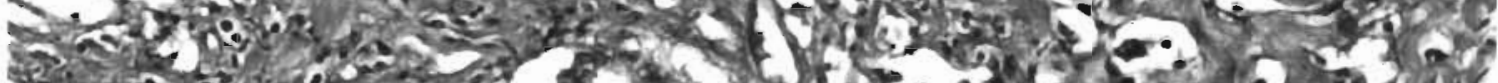
to.

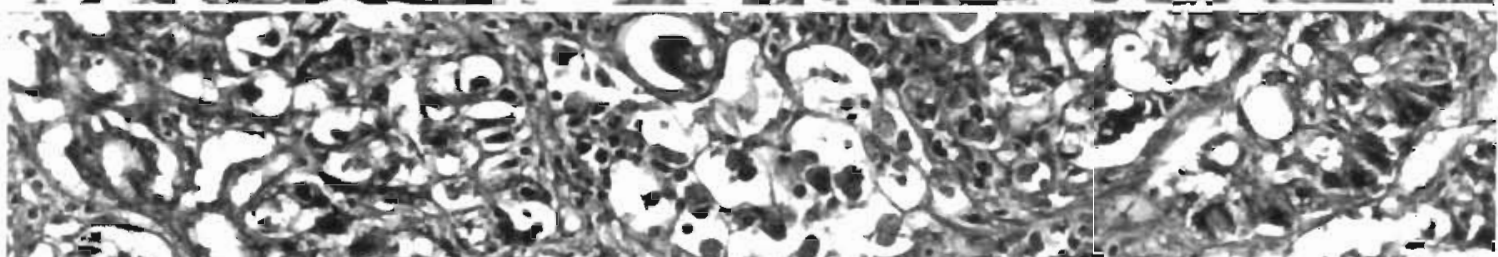

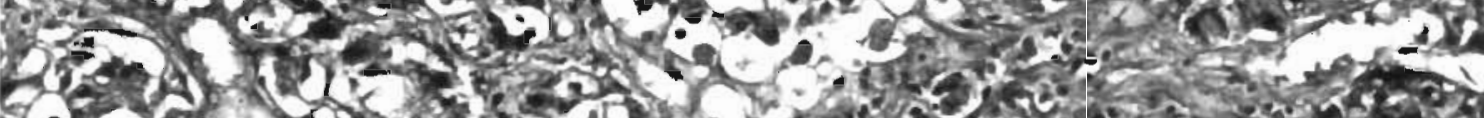

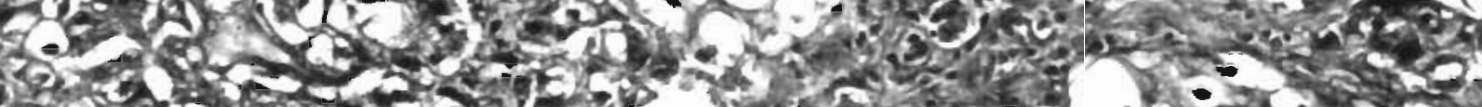

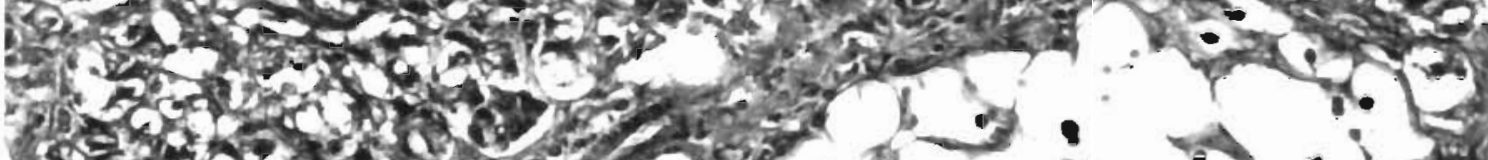

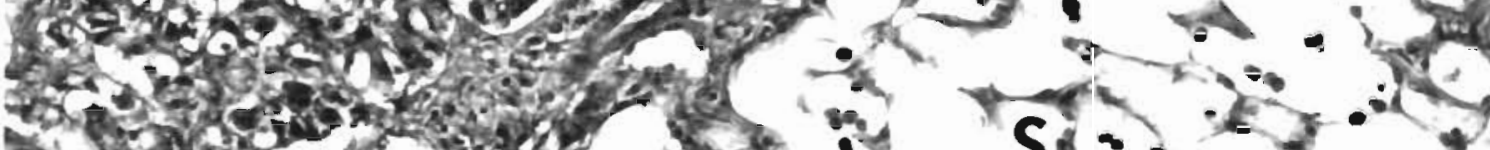

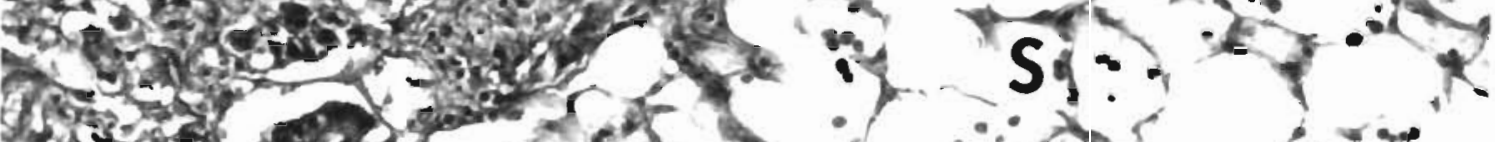

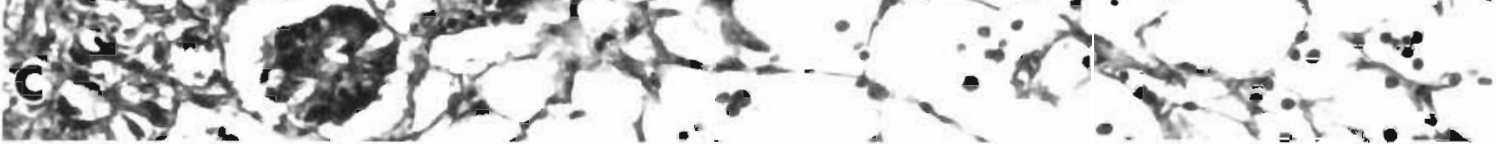


tumorigenesis. There appears to be a much higher sensitivity of the early life stages of fish, than of adults, to experimentally administered carcinogens. This sensitivity presumably reflects the high cell proliferation rate in the liver of young fish, with an increased chance of fixation of genetic damage including parenchymal cells. However, there has yet to be a description of liver tumors in wild fish during their first year Indeed, in this study the youngest age recorded for a tumor-bearer was $5 \mathrm{yr}$. This is not to suggest that young feral fish in contaminated habitats are not exposed to genotoxic compounds, rather that tumorigenesis may require repeated exposure to these compounds, and/or subsequent exposure to sufficient doses of epigenetic carcinogens. We have previously attempted to elicit tumorigenesis in adult winter flounder by exposing them to dietary aromatic and halogenated hydrocarbons. The only response we saw was a proliferation of peribiliary epithelia (Moore 1991), which appeared comparable to the oval cell reaction described in hepatocarcinogenesis studies in mammals (Sell \& Leffert 1982).

The teleost liver, lacking the radial symmetry of lobules, has a relatively primitive organization as compared to mammals. Information on the pathogenesis of liver neoplasia within this liver may aid in resolving current controversies. One such controversy has focused on the relative significance of altered foci of hepatocytes versus primitive biliary epithelia, such as oval cells, in mammalian hepatocarcinogenesis (Sell \& Lefert 1984). The cell associations we have described bear on this controversy. In the winter flounder, the cell type most intimately associated with the majority of the neoplastic lesions described in this study is the vacuolated cell. This cell appears to be an abnormal epithelial cell that contains a large vacuole that develops in response to chronic exposure to cytotoxins. Adjacent to many vacuolated cells there are small, ovoid, basophilic cells that are not vacuolated and have scant cytoplasm. Both of these cell types appear to be proliferative (Moore \& Stegeman 1992, Koza et al. 1993). In a survey of multiple sites on the U.S. East Coast, the prevalence of hydropic vacuolation was found to correlate closely with levels of polynuclear aromatic hydrocarbons and chlordanes in sediment and stomach contents in winter flounder, starry flounder and white croaker (Johnson et al. 1992, Myers et al. 1994). We have also shown that the first cell to undergo vacuolation is a biliary preductular cell (Moore et al. 1989). Biliary epithelial cells in fish have been described by some as oval cells (Hampton et al. 1988). Moreover, as discussed above, we have induced an 'oval cell response' in winter flounder following chemical exposure. It is possible, therefore, that there is some form of functional homology between vacuolated and poorly differentiated biliary epithelia in winter flounder and the oval cell in rodents (Sell \& Salman 1984, Tsao \& Grisham 1987) and other fish (Couch \& Courtney 1987). Whether other similarities occur between fish preductular and mammalian oval cells is not known. Further characterization of the preductular cell in flounder, and its proliferation could substantiate this possibility.

Acknowledgements. We thank Roxanna Smolowitz and Bruce Woodin for assistance with this study, and 3 anonymous reviewers for their comments. Funded in part by PHS CA 44306, and The Donaldson Charitable Trust. WHOI Contribution Number 8803 .

\section{LITERATURE CITED}

Bannasch, P., Bloch, M., Zerban, H. (1981). Spongiosis hepatis. Specific changes of the perisinusoidal liver cells induced in rats by $\mathrm{N}$-nitrosomorpholine. Lab. Invest. 44 : $252-264$

Baumann, P. C., Smith, W. D. Parland, W. K. (1987). Tumor frequencies and contaminant concentrations in brown bullheads from an industrialized river and a recreational lake. Trans. Am. Fish. Soc. 116: 79-86

Black, J. J., Maccubbin, A. E., Schiffert, M. (1985). A reliable, efficient, microinjection apparatus and methodology for the in vivo exposure of rainbow trout and salmon embryos to chemical carcinogens. J. natn Cancer Inst. 75: $1123-1128$

Bodammer, J. E., Muchelano, R. A. (1990). Cytological study of vacuolated cells and other aberrant hepatocytes in winter flounder from Boston Harbor. Cancer Res. 50: 6744-6756

Boehm, P. D. (1984). Organic pollutant contamination of the Boston Harbor - Massachusetts Bay - Cape Cod Bay System - sediments and biota. NOAA Final Report Contract No. NA-83-FA-C-00022 1: 1-61

Couch, J., Courtney, L. (1987). N-nitroso-di-ethylamineinduced hepatocarcinogenesis in estuarine sheepshead minnow (Cyprinodon variegatus): neoplasms and related lesions compared with mammalian lesions. J. natn Cancer Inst. 79: 297-321

Gardner, G. R., Pruell, R. J. (1988). A histopathological and chemical assessment of winter flounder, lobster, and softshelled clam indigenous to Quincy Bay, Boston Harbor, and in-situ evaluation of oysters including sediment (sur-

Fig. 8. Pleuronectes americanus. An invasive scirrhous cholangiocellular carcinoma in a winter flounder liver. Paraffin-embedded sections $(\mathrm{H} \& \mathrm{E})$. This tissue section was not deposited with the RTLA. (a) Extensive fibrotic tracts ensheath degenerate neoplastic cells (arrowheads). Collagen specific stains, not shown, confirmed the presence of collagen. 25×. (b) An area of (a) where fibroplasia is extensive (F). 200x. (c) A higher power view of the bottom right corner of (a). Spongiosis hepatis is evident (S). Note the differences between spongiosis hepatis as illustrated here and the vacuolated cells evident in many of the other figures. $200 \times$ 
face and cores chemistry. EPA Task Report. U.S. EPA, Narragansett, RI

Hampton, J. A. Lantz, R. C., Goldblatt, P. J., Lauren, D. J., Hinton, D. E. (1988). Functional units of the rambow trout (Salmo gairdneri) liver: II. The biliary system. Anat. Rec. $221.619-634$

Harshbarger, J. C., Clark, J. B. (1990). Epizootiology of neoplasms in bony fish of North America. Sci. total Environ. 94: $1-32$

Hawkins, W. E., Walker, W. W., Overstreet, R. M., Lytle, J. S., Lytle, T F. (1990). Carcinogenic effects of some polycyclic aromatic hydrocarbons on the Japanese medaka and guppy in water borne exposures. Sci. total Environ. 94: $155-167$

Hayes, M. A., Smith, I. R., Rushmore, T H., Crane, T L., Thorn, C., Kocal, T E., Ferguson, H. W. (1990). Pathogenesis of skin and liver neoplasms in white suckers from industrially polluted areas in Lake Ontario. Sci. total Environ. 94: 105-123.

Hendricks, J. D., Meyers, T R., Shelton, D. W., Casteel, J. L., Bailey, G. S. (1985). Hepatocarcinogenicity of benzo(a)pyrene to rainbow trout by dietary exposure and intraperitoneal injection. J. natn Cancer Inst. 74.4: $839-851$

Hoover, K. L. (ed.) (1984). Use of small fish species in carcinogenicity testing. Natn Cancer Inst. Monogr. 65: 1-404

Johnson, L. L., Stehr, C. M., Olson, O. P., Myers, M. S., McCain, B. B., Chan, S. L., Varanasi, U. (1992). National Status and Trends Program, National Benthic Surveillance Project, Northeast Coast. Fish histopathology and relationships between lesions and chemical contaminants (1987-89). NOAA Tech. Mem. NMFS-NWFC-4

Koza, R. A., Moore, M. J., Stegeman, J. J. (1993). Elevated ornithine decarboxylase activity and cell proliferation in neoplastic and vacuolated liver cells of winter flounder (Pleoronectes americanus). Carcinogenesis 14:399-405

Landahl, J. I., McCain, B. B., Myers, M. S., Rhodes, L. D., Brown, D. W. (1990). Consistent associations between hepatic lesions in English sole (Parophrys vetulus) and polycyclic aromatic hydrocarbons in bottom sediment. Environ. Health Perspect. 89: 195-203

Luna, L. G. (1968). Manual of histologic staining methods of the Armed Forces Institute of Pathology, 3rd edn. McGraw-Hill, New York, p. 1-258

Moore, M. J. (1991) Vacuolation proliferation and neoplasia in the liver of Boston Harbor winter flounder (Pseudopleuronectes americanus). Woods Hole Oceanogr. Inst. Technical Doc. 91-28: 1 - 268

Moore, M. J., Smolowitz, R., Stegeman, J. J. (1989). Cellular alterations preceding neoplasia in (Pseudopleuronectes

Responsible Subject Editor: D. E. Hinton, Davis, Callfornia, USA amencanus) from Boston Harbor Mar. environ. Res. 28 $425-429$

Moore, M. J., Stegeman, J. J. (1992). Bromodeoxyuridine uptake in hydropic vacuolation and neoplasms in winter flounder liver. Mar. environ. Res. 34-13-18

Murchelano, R. A., Wolke, R. (1985). Epizootic carcinoma in the winter flounder (Pseudopleuronectes americanus). Science 228: 587-589

Murchelano, R. A., Wolke, R. (1991). Neoplastic and nonneoplastic liver lesions in winter flounder (Pseudopleuronectes americanus] from Boston Harbor, Massachusetts. Environ. Health Perspect. 90: 17-26

Myers, M. S., Landahl, J. T., Krahn, M. M., Johnson, L. L., McCain, B. B. (1990). Overview of studies on liver carcinogenesis in English sole from Puget Sound; evidence for a xenobiotic chemical etiology 1 Pathology and epizootiology. Sci. total Environ. 94: 33-50

Myers, M. S., Stehr, C. S., Olson, O. P., Johnson, L. L., McCain, B. B., Chan, S.L., Varanasi, U. (1994). Relationships between toxicopathic hepatic lesions and exposure to chemical contaminants in English sole (Pleuronectes vetulus), starry flounder (Platichthys stellatus), and white croaker (Genyonemus stellatus) from seleted marine sites on the $\mathrm{Pa}-$ cific Coast, USA. Environ. Health Perspect. 102: 200-215

NOAA (1988). A summary of selected data on chemical contaminants in sediments collected during 1984-1987 NOAA Tech. Mem. NOS OMA 44

Sell, S., Leffert, H. L. (1982). An evaluation of cellular lineages in the pathogenesis of experimental hepatocellular carcinoma. Hepatology 2: 77-86

Sell, S., Salman, J. (1984). Light- and electron-microscopic autoradiographic analysis of proliferating cells during the early stages of chemcial hepatocarcinogenesis in the rat induced by feeding $\mathrm{N}$-2-fluorenylacetamide in a cholinedeficient diet. Am. J. Pathol 114:287-300

Shiaris, M. P., Jambard-Sweet, D. (1986). Polycyclic aromatic hydrocarbons in surficial sediments of Boston Harbor, MA, USA. Mar. Pollut. Bull. 17: 469-472

Schultz, M. E., Kaplan, L. A. E., Schultz, R. J. (1989). Initiation of cell proliferation in the livers of the viviparous fish Poeciliopsis lucida with 7,12-dimethylbenz\{a\}thracene. Environ. Res. 48: 248-254

Tsao, M.-S., Grisham, J. W. (1987). Hepatocarcinomas, cholangiocarcinomas, hepatoblastomas produced by chemically transformed cultured rat liver epithelial cells. Am. J. Pathol. 127: 168-181

Vogelbein, W. K., Fournie, J. W, van Veld, P. A.. Huggett, R. J. (1990). Hepatic neoplasms in the mummichog Fundulus heteroclitus from a creosote-contaminated site. Cancer Res. 50: 5978-5986

Manuscnpt first received: July 29, 1993

Revised version accepted: July 18, 1994 